\title{
COMPARATIVE ANALISYS OF AGRO-FOOD TRADE IN MONTENEGRO AND EU CANDIDATE COUNTRIES
}

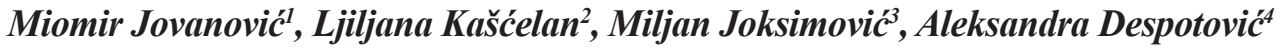

\begin{abstract}
Summary
The aim of the paper was the analysis of the competitiveness and changes in the foreign trade of the Montenegro from 2006-2013. The main contribution of the work was supplemented by the comparison of the Montenegro agro-food trade performance with candidate and potential candidate EU countries. Taking into account the many differences among the analyzed countries we used an unconventional methodical practice based on the calculation of trade balance per one inhabitant. During the analyzed period, only 2 countries exceeded the level of $100 \%$ self-sufficiency and permanently reached the positive trade balance with agricultural and food products. As to the "self-sufficiency level" calculated on the basis of the average trade balance per one inhabitant in 2006-2013 within the candidate and potential candidate EU countries the last position belongs to the Montenegro closely before Albania and Bosnia and Herzegovina.
\end{abstract}

Key words: agro-food trade, foreign trade, efficiency, competitiveness.

JEL: $F 10, Q 18$

\section{Introduction}

The Montenegro is a small and open economy. Montenegro's economy was slowly transitioning to a market system. Unemployment and disparities in regional development, especially in the north, remain key political and economic problems. In the Montenegro,

1 Miomir Jovanović, Ph.D., University of Montenegro, Biotechnical Faculty Podgorica, Department for Agro Economic Research, Mihalila Lalića Street no. 15, 81000 Podgorica, Montenegro, Phone: +382 693206 23, E-mail: miomirj@ac.me

2 Ljiljana Kašćelan, Ph.D., Full Professor, University of Montenegro, Faculty of Economics, Jovana Tomaševica Street no. 37, 81000 Podgorica, Montenegro Phone: +382 690580 61, E-mail: ljiljak@ac.me

3 Miljan Joksimović, M.Sc., Assistant, University of Montenegro, Biotechnical Faculty, Department for Agro Economic Research, Mihalila Lalića Street no. 15, 81000 Podgorica, Montenegro, Phone: +382684386 25, E-mail: miljanj@ac.me

4 Aleksandra Despotović, Ph.D., Associate Professor, University of Montenegro, Biotechnical Faculty Podgorica, Department for Agro Economic Research, Mihalila Lalića Street no. 15, 81000 Podgorica, Montenegro, Phone: +382 693063 30, E-mail: alexd@t-com.me

EP 2015 (62) 1 (155-162) 
the past decade was characterized by the reduction and concentration of the food industry and the retail network. The neglect of agriculture had a negative impact on the growth of GDP, employment, the external current account deficit and initiated the migration from rural to urban areas of the country (Fabris, Pejović, 2012). However, one of the structural characteristics of Montenegrin food production is a higher share of primary agriculture in gross domestic product than of food-processing sector. The 2006 dissolution of the loose political union between Serbia and Montenegro led to separate memberships in several international financial institutions such as the EBRD, World Bank, IMF and WTO. The European Council (EC) granted candidate country status to Montenegro at the December 2010 session. Montenegro began negotiations to join the EC in June, 2012. Transition to a market economy, trade liberalization, free trade agreements, regional European reintegration and rapid adjustments to EU membership might have induced substantial changes in the structures of agro-food trade flows and changes in comparative advantages. The agriculture has a special place in the process of free trade given the usually limited effects in the liberalization of agricultural products (Ćejvanović et al, 2014). Since the very beginning of the integration, agriculture in the European Union has been one of the most important sectors (Antevski et al., 2012). Transformation of national agri-food trade was one of the major changes indicated by several authors (Fertö, 2008; Baráth et al., 2010; Svatos, Smutka, 2011).However, research on comparative trade advantages for agro-food trade in CEBCs is still relatively rare (Bojnec, Ferto, 2009). This has motivated our research to investigate agro-food trade developments and trade advantages between Montenegro and candidate and potential candidate EU countries during the pre-enlargement period in order to derive broader policy implications for agro-food trade and sustainable agro-food sector development. Montenegro has close commercial relationships with various countries on different continents, but the main trade partners are the European countries. The main trade partners were EU-28 and CEFTA for export with share of $56 \%$ and for import of 38\%. The main trade partner countries were Serbia, Italy, Greece, Slovenia, Hungary and Germany. Since 2006, the share of the EU countries in the total Montenegro s trade has constantly increased. According to relationship existing between Montenegro and the EU-27 the agro-food trade has been intensified. The main agro-food product groups from export and import point of view are: beverages, tobacco, meat and meat preparations, vegetables and fruit, cereal and cereal products and fish and preparations according to the statistical classification. In the period 2006-2013 all the agro-food product groups expect beverages and tobacco registered an important growth. Regarding to export of agro-food products, meat and meat preparations were on the top position followed by vegetables and fruit and cereal and cereal products. Regarding import, the highest value belonged to meat and meat preparations, followed on the second position by vegetable products and fruits, on the third position by cereal and cereal products, than beverage and tobacco and on the last one by fish and fish preparations (Jovanović, Despotović, 2014). 


\section{Material and methods}

Data used in the contribution were derived from the Statistical Office of the Montenegro (MONSTAT) and the Statistical Office of the European Union (EUROSTAT). The adequate long time series (from 2006 to 2013) was selected in order to enhance the authenticity of the reached results. During the last half of the century, applied trade literature has developed three main concepts for measuring comparative advantages, trade specialization and trade competitiveness: relative comparative trade advantage measures, intra industry trade indices and categories of price and quality competition in two-way trade and non price competition in one-way trade (Bojnec and Ferto, 2012). There were variations and large differentials in the border barrier in bilateral trade flows between European Union (EU) countries (Minondo, 2007). Western Balkan countries are quite different, but they can be characterized by their shared goal, which is the quickest possible accession to the European Union (Mizik, 2014). So, we tried to evaluate the impact of the foreign agro-food trade on the consumption structure of inhabitants in the candidate and potential candidate EU countries - Turkey, Serbia, Republic of Macedonia, Bosnia and Herzegovina, Albania and Montenegro. There were no available data series for Iceland and Kosovo. In order to analyze the trends of the agro-food foreign trade, the specific indicators have been used by different authors such as the volume of export, import and balance, the share of agro-food export, import and balance in foreign trade, the value and structure of agro-food export FOB and also of agro-food import CIF by section and main chapters according to the Combined Nomenclature, $\mathrm{CN}$, the export impact on GDP, the import coverage by export, export value per inhabitant, export/agricultural production value were also determined using the formulas (Anghelache, 1999) and (Popescu, 2010). At the same time a few methods and indicators were used for the international comparison of the foreign agro-food trade. Several methods frequently used in the analysis of foreign trade models are based upon the calculation of the trade comparative advantage indices (Rusali, 2012). The position of agro-food trade of a given country can be judged in different ways. One way is to analyze the indicator of competitiveness (Bielik, Qineti, 2010). We used in this paper the final consumer of agrarian and food products or the consumer with a very similar structure of the basic consumption basket. The calculation per 1 inhabitant is eligible for the international comparison (Matošková, Gálik, 2009). In terms of balance, using of the calculation of the total agro-food trade balance per 1 inhabitant seems to be optimal. The scientific notation of the mentioned calculations is presented as follows:

$$
\begin{aligned}
& \mathrm{PSOMM}=\mathrm{PSO} / \mathrm{MMM} \mathrm{X} 100 \\
& \mathrm{PM}=\mathrm{PSOMM} / \mathrm{PVP}
\end{aligned}
$$

Where: PSOMM = share of the agro food foreign trade balance per1 inhabitant, calculated per monthly minimal wage (in \%); PSO = share of foreign trade balance calculated per 1 inhabitant (in $€$ ); $\mathrm{MMM}=$ minimal monthly wage (in $€$ ); $\mathrm{PM}=$ number of months; $\mathrm{PVP}=$ share of expenditures (on food stuffs, tobacco and alcohol) in the disposable income of an inhabitant (in \%). 


\section{Results and discussion}

Montenegro's foreign trade has recorded continuous changes in the analyzed period. Export decreased from 443 mill $€$ in 2006 to 372 mill $€$ in 2013, while the import growth up from 1467 mill. $€$ in 2006 to 1.769 mill $€$ in 2013. Therefore, import value was higher than export value. As a result, the trade balance was a negative one registering a higher deficit from 2006 to 2008 and then its figure was much lower. Thus, in 2013 the deficit of Montenegro's trade balance accounted for 1.396 mill $€$ and being by $36.4 \%$ higher than in 2006 . Since 2006, the goods exchange regarding agro-food products has been more intensive. In the analyzed period, the average of the negative agro-food trade balance shared in the total trade was $22 \%$. The average value in the mentioned period of agro-food balance was $325.8 \mathrm{mil}$ $€$ (MONSTAT). Consequently, the agro-food trade shared with $17.9 \%$ in the total trade balance in 2006 and with $16.1 \%$ in 2008. In 2009, the development was impacted by the world economic crisis. The total Montenegrin export decreased as much as by $2.2 \%$ per annum, the agro-food import increased by $2.4 \%$ (Table1). The economic crisis affected more strongly the total import its value was decreased from 2008 to 2013 by $-5.9 \%$. At the same time the import of agricultural and food products increased by $1.1 \%$. A higher decline rate of import as compared to export was proved at a markedly negative total trade balance at the level of -1.635 mill $€$. The opposite development was recorded by the agro-food commodities. It resulted in the trade balance deterioration - to the highest negative value of -379.4 mill $€$ (2013) in the history of the Montenegro.

Table 1. Indicators of the total and foreign trade of the Montenegro (in mill $€$ )

\begin{tabular}{|l|r|r|r|r|r|r|r|r|r|}
\hline Indicators & $\mathbf{2 0 0 6}$ & $\mathbf{2 0 0 7}$ & $\mathbf{2 0 0 8}$ & $\mathbf{2 0 0 9}$ & $\mathbf{2 0 1 0}$ & $\mathbf{2 0 1 1}$ & $\mathbf{2 0 1 2}$ & $\mathbf{2 0 1 3}$ & $\begin{array}{c}\text { Average } \\
\mathbf{0 6 - 1 3}\end{array}$ \\
\hline Total export & 443 & 457 & 419 & 278 & 329 & 451 & 365 & 372 & 389.2 \\
\hline Total import & 1,467 & 2,092 & 2,537 & 1,658 & 1,646 & 1,828 & 1,818 & 1,769 & 1,851 \\
\hline $\begin{array}{l}\text { Total trade } \\
\text { balance }\end{array}$ & $-1,023$ & $-1,635$ & $-2,118$ & $-1,381$ & $-1,317$ & $-1,377$ & $-1,454$ & $-1,396$ & $-1,462$ \\
\hline $\begin{array}{l}\text { Agro-food } \\
\text { export }\end{array}$ & 36.6 & 37.2 & 41.0 & 40.3 & 44.9 & 50.5 & 53.2 & 53.4 & 12.75 \\
\hline $\begin{array}{l}\text { Agro-food } \\
\text { import }\end{array}$ & 220.0 & 300.9 & 404.6 & 380.6 & 384.8 & 418.8 & 421.2 & 432.8 & 370.5 \\
\hline $\begin{array}{l}\text { Agro-food } \\
\text { balance }\end{array}$ & -183.4 & -263.7 & -363.6 & -340.3 & -339.9 & -368.3 & -368.0 & -379.4 & -325.8 \\
\hline $\begin{array}{l}\text { Agro-food / } \\
\text { total balance (\%) }\end{array}$ & 17.9 & 16.1 & 17.1 & 24.6 & 25.8 & 26.7 & 25.3 & 27.1 & 22.2 \\
\hline $\begin{array}{l}\text { Agro- food trade } \\
\text { value }\end{array}$ & 256.6 & 338.1 & 445.6 & 420.9 & 429.7 & 469.3 & 474.4 & 486.2 & 415.1 \\
\hline
\end{tabular}

Source: Authors calculations according to data from EUROSTAT. 
Table 1a. Descriptive statistics analysis

\begin{tabular}{|c|c|c|c|c|c|c|c|c|}
\hline Indicators & Row1 & Row2 & Row3 & Row4 & Row5 & Row6 & Row7 & Row8 \\
\hline Mean & 389.25 & 1851.875 & -1462.625 & 44.6375 & 370.4625 & -325.825 & 22.575 & 415.1 \\
\hline Standard Error & 22.783727 & 116.78299 & 111.17986 & 2.451307 & 25.963016 & 24.06543 & 1.6538645 & 27.946901 \\
\hline Median & 395.5 & 1793.5 & -1388.5 & 42.95 & 394.7 & -351.95 & 24.95 & 437.65 \\
\hline $\begin{array}{l}\text { Standard } \\
\text { Deviation }\end{array}$ & 64.442111 & 330.31216 & 314.46414 & 6.9333433 & 73.434498 & 68.067314 & 4.6778353 & 79.045773 \\
\hline $\begin{array}{l}\text { Sample } \\
\text { Variance }\end{array}$ & 4152.7857 & 109106.13 & 98887.696 & 48.07125 & 5392.6255 & 4633.1593 & 21.882143 & 6248.2343 \\
\hline Kurtosis & -0.6946283 & 2.2674736 & 2.9287839 & -1.900847 & 1.7558615 & 2.1779641 & -2.0194855 & 1.3681655 \\
\hline Skewness & -0.6312897 & 1.3836556 & -1.2072567 & 0.252424 & -1.5456074 & 1.6692276 & -0.5821368 & -1.4190582 \\
\hline Range & 179 & 1070 & 1095 & 16.8 & 212.8 & 196 & 11 & 229.6 \\
\hline Minimum & 278 & 1467 & -2118 & 36.6 & 220 & -379.4 & 16.1 & 256.6 \\
\hline Maximum & 457 & 2537 & -1023 & 53.4 & 432.8 & -183.4 & 27.1 & 486.2 \\
\hline Sum & 3114 & 14815 & -11701 & 357.1 & 2963.7 & -2606.6 & 180.6 & 3320.8 \\
\hline Count & 8 & 8 & 8 & 8 & 8 & 8 & 8 & 8 \\
\hline Largest(1) & 457 & 2537 & -1023 & 53.4 & 432.8 & -183.4 & 27.1 & 486.2 \\
\hline Smallest $(1$ & 278 & 1467 & -2118 & 36.6 & 220 & \begin{tabular}{|l|}
-379.4 \\
\end{tabular} & 16.1 & 256.6 \\
\hline $\begin{array}{l}\text { Confidenc } \\
\text { Level } \\
(95.0 \%)\end{array}$ & 53.874953 & 276.14788 & 262.8986 & 5.7964201 & 61.392777 & 56.905699 & 3.9107682 & 66.08392 \\
\hline
\end{tabular}

Source: Calculations according to data from EUROSTAT, (Table 1).

Many authors used different methods and indicators for the evaluation of competitiveness of the foreign trade with its positives and negatives. But, main focus is on the consumer of agricultural and food products as the consumer with a very close structure of the basic consumption basket. In this connection, it is practice to use the calculation per one inhabitant for the international comparison and for the comparison of the agro-food foreign trade efficiency. The commodity foreign trade exchange is the bilateral trade relation (import and export of goods). So it seems to be optimal to use the calculation of the total agro-food trade balance per one inhabitant (Table 2).

Table 2. The share of the foreign trade balance calculated per 1 inhabitant ( $€$ )

\begin{tabular}{|l|r|r|r|r|r|r|r|r|r|}
\hline States & $\mathbf{2 0 0 6}$ & $\mathbf{2 0 0 7}$ & $\mathbf{2 0 0 8}$ & $\mathbf{2 0 0 9}$ & $\mathbf{2 0 1 0}$ & $\mathbf{2 0 1 1}$ & $\mathbf{2 0 1 2}$ & $\mathbf{2 0 1 3}$ & $\begin{array}{c}\text { Average } \\
\mathbf{0 6 - 1 3}\end{array}$ \\
\hline Turkey & 62.3 & 54.3 & 43.9 & 60.0 & 67.0 & 56.91 & 70.9 & 77.8 & 61.6 \\
\hline Serbia & 39.5 & 52.3 & 41.3 & 87.1 & 114.5 & 94.4 & 119.5 & 105.7 & 81.8 \\
\hline $\begin{array}{l}\text { Republic of } \\
\text { Macedonia }\end{array}$ & -7.0 & -34.4 & -223.4 & -46.0 & -31.2 & -46.3 & -67.1 & -45.5 & -62.6 \\
\hline $\begin{array}{l}\text { Bosnia and } \\
\text { Herzegovina }\end{array}$ & -0.2 & -0.2 & -269.4 & -0.2 & -0.2 & -272.0 & -272.5 & -263.1 & -134.7 \\
\hline Albania & -121.0 & -143.7 & -168.9 & -161.5 & -181.7 & -186.1 & -186.7 & -184.4 & -166.8 \\
\hline Montenegro & -294.1 & -421.9 & -579.4 & -540.0 & -549.9 & -594.1 & -593.2 & -611.0 & -522.9 \\
\hline
\end{tabular}

Source: Authors calculations according to data from EUROSTAT.

According to calculation in table 1 it is possible to analyze the degree of self-sufficiency of the individual countries on the assumption that the inhabitants basic living needs. During the analyzed period, only 2 countries exceeded the level of $100 \%$ self-sufficiency and permanently reached the positive trade balance with agricultural and food products. In the 
long term, the privileged position belongs to the Serbia that registered the "surplus" of products (approximately $81.8 €$ per inhabitant). The full self-sufficiency degree is exceeded very significantly also in the sectors of Turkey. As to the "self-sufficiency level" calculated on the basis of the average trade balance per one inhabitant in 2006-2013 within the candidate and potential candidate EU countries the last position belongs to the Montenegro closely before Albania and Bosnia and Herzegovina. The share of the trade balance per one inhabitant is very important for estimation of its impact on the structure of the inhabitants' consumption. But, it is not possible to do it directly and exactly. The main reason is because the data on the foreign trade indicate only the value of the traded goods. It means they do not reflect the level of consumer prices. In this connection the data on the agro-food foreign trade balance per one inhabitant are taken as a value. At the same time, the different income level of the population in the individual candidate and potential candidate EU countries must be taken into account. The level of the minimal monthly wage was used in the calculations because its impact on the level of living standard in the analyzed countries. To simplify the average expenditures on food, tobacco and alcohol accounts to $15 \%$ of the disposable income in developed countries. In the Montenegro, the share of food expenditures accounts from 30 to $42 \%$ from the disposable income. The similar share was also used for other candidate and potential candidate EU countries. The agro-food sector and trade of the Serbia and Turkey is able to generate surplus every year or surplus equivalent to the level of the expenditures on food, tobacco and alcohol of an inhabitant whose income reached the minimal wage level for 1.4 and 1.3 months (Table 3).

Table 3. The share of the foreign trade balance in the EU per inhabitant, calculated per minimal monthly wage (in \%)

\begin{tabular}{|l|r|r|r|r|r|r|r|r|r|}
\hline States & $\mathbf{2 0 0 6}$ & $\mathbf{2 0 0 7}$ & $\mathbf{2 0 0 8}$ & $\mathbf{2 0 0 9}$ & $\mathbf{2 0 1 0}$ & $\mathbf{2 0 1 1}$ & $\mathbf{2 0 1 2}$ & $\mathbf{2 0 1 3}$ & $\begin{array}{c}\text { No. of } \\
\text { month }\end{array}$ \\
\hline Serbia & 753.2 & 768.4 & 1172.0 & 642.7 & 410.4 & 488.1 & 432.3 & 480.6 & 1.4 \\
\hline Turkey & 672.3 & 749.5 & 1098.7 & 0 & 751.6 & 1008.5 & 754.1 & 0 & 1.3 \\
\hline Montenegro & -72.4 & -58.2 & -58.3 & -77.0 & -84.1 & -80.6 & -81.5 & -79.6 & -0.2 \\
\hline Albania & -180.9 & -162.0 & -161.6 & 0 & -170.5 & -173.0 & -178.2 & -195.1 & -0.5 \\
\hline $\begin{array}{l}\text { Bosnia and } \\
\text { Herzegovina }\end{array}$ & -126.7 & -127.8 & -122.4 & 0 & -167.9 & -149.6 & -153.0 & 0 & -1.4 \\
\hline $\begin{array}{l}\text { Republic of } \\
\text { Macedonia }\end{array}$ & -293.0 & -642.0 & -106.5 & -569.1 & -1042.5 & -720.2 & -504.5 & -745.9 & -3.2 \\
\hline
\end{tabular}

Source: Authors calculations according to data from EUROSTAT.

Note: The number of months calculated from the average value of 2006-2013.

It means the demand for food of their population (with the minimal income) for one year and four month can be covered is able to cover by the domestic resources generated within one year in the Serbia. In spite of the different living standard and the structure of expenditures, the agro-food sector covers the food demand of its population with minimal income from domestic resources for one year and four months in Serbia and for one year and three months in Turkey. The Montenegrin agro-food sector and trade is not able to cover the domestic demand. It means that with the view to mitigate his/ her basic living needs an inhabitant of the Montenegro (whose income is at the minimal 
wage level) must consume the imported foodstuffs approximately for 0.2 months within one year. An extreme case is Republic of Macedonia and Bosnia and Herzegovina, where the annual deficit of the foreign trade is equivalent to the level of expenditures on food, tobacco and alcohol of an inhabitant, whose income reached the minimal wage level for 3.2 and 1.4 months.

\section{Conclusions}

Since 2006, Montenegrin producers and exporters have been adapting to the changed conditions and they have been switched to trading in the EU and especially CEFT-a market. The WTO commitment concerning the elimination of all forms of export subsidies evoked the tendency to reduce the surplus of the commodities depending on export subsidies. The negative trade balance of the trade has been permanently deepened in Montenegro. The negative trade development culminated in 2008 when the highest negative trade balance of $€-2.118$ million was recorded within the Montenegro history. The year 2009 was affected by the world economic crisis. The crisis resulted in the growth of the share of the foreign trade balance in the Serbia and Turkey per 1 inhabitant and the decrease of real incomes and the purchasing power of households and consequently to the demand decrease in other candidate and potential candidate countries. In 2009 as compared to the previous year, there were imported to Montenegro less agro food products than in 2008. At the same time, in the 2009 is exported less than in previous period. But, during the analyzed period the crisis was provided better position for domestic food exporter. They recorded the growth of the export. During the analyzed period, only 2 countries exceeded the level of $100 \%$ selfsufficiency and permanently reached the positive trade balance with agricultural and food products. In the long term, the privileged position belongs to the Serbia that registered the "surplus" of products (approximately $81.8 €$ per inhabitant). In spite of the different living standard and the structure of expenditures, the agro-food sector covers the food demand of its population with minimal income from domestic resources for one year and four months in Serbia and for one year and three months in Turkey.

\section{Literature}

1. Fabris, N., Pejović, I. (2012): Poljoprivreda Crne Gore - dijagnoza i preporuke za unapredjenje stanja, Economics of agriculture, Belgrade, vol. 59, br. 4, pp. 657-673.

2. Bojnec, Š., Ferto, I. (2009): Agro-food trade competitiveness of Central European and Balkan countries, Food Policy, vol. 34, pp. 417-425.

3. Bojnec, Ц̆., Ferto, I. (2012): Complementarities of trade advantage and trade competitiveness measures, Applied Economics, no. 44, pp. 399-408.

4. Minondo, A. (2007): The disappearance of the border barrier in some European Union countries'bilateral trade, Applied Economics, no. 39, pp. 119-124.

5. Fertö, I. (2008): The evolution of agri-food trade patterns in Central European countries, Post-Communist Economies, vol. 20, no. 1, pp. 1-10.

6. Baráth, L. Nagy, Zs., Szabó, G. (2010): The correlation between the agricultural 
productivity and the export performance of the agro-food foreign trade in the Visegrád Group countries following accession to the European Union, Studies in Agricultural Economics, no. 112, pp. 55-68.

7. Svatos, M., Smutka, L. (2011): The analysis of individual visegrad group members'agrarian export sensitivity in relation to selected macroeconomic aggregations, Acta universitatis agriculturae and silviculturae mendelianae brunensis, vol. 59, no. 4, pp. 327-340.

8. Antevski, M., Petrović, P., Vesić, D. (2012) Development perspectives in agriculture and rural areas in Serbia in the EU integration process, Economics of agriculture, vol. 59, no. 2, pp. 243-250.

9. Ćejvanović, F., Ivanković M., Lasić, M., Vaško, Ž. (2014): The impact of foreign trade in agricultural products of Bosnia and Herzegovina within the framework of cefta 2006, Economics of Agriculture, vol. 61, no. 4 2014, pp. 975-978.

10. Jovanović, M., Despotović, A. (2014): Analysis of position of agro-food trade in Montenegro's foreign trade, Agriculture \& Forestry, vol. 60, no. 1, pp. 235-243.

11. Mizik, T. (2014): Land, as a bottleneck of the Western Balkans 'agriculture, proceedings, $142^{\text {nd }}$ EAAE Seminar - Growing Success? Agriculture and rural development in an enlarged EU, Corvinus University of Budapest, Budapest, Hungary, pp. 1-12.

12.EUROSTAT, Statistics, portal of Eurostat, available at: http://epp.eurostat.ec.europa.eu, accessed at: February, 2015.

13. Anghelache, C. (1999): Foreign trade-Finance and financial-banking analysis, Economical Press House, Bucharest.

14. Popescu, A. (2010): Home and Foreign Trade, Dominor Publishing House, Bucharest, pp. 270-296.

15. Rusali, M. (2012): EU accession impacts on the comparative advantages in agricultural trade: Romania's case, Economics of Agriculture, vol. 59, no. 4, pp. 747-753.

16. Bielik, K., Qineti, A. (2010): The position of Czech and Slovak agro-food trade in the European markets, Delhi Business Review X, vol. 11, no. 2, pp. 1-10.

17. Matošková, D., Gálik, J. (2009): Selected aspects of the internal and external competitiveness of Slovak agricultural and food products, Agricultural Economics Czech, vol. 55, pp. 84-93.

18. Statistical Office of the Montenegro (MONSTAT), "SY MNE - 2014, PAGE. 1-274", portal of MONSTAT, available at: www.monstat.org, accessed at: February, 2015. 